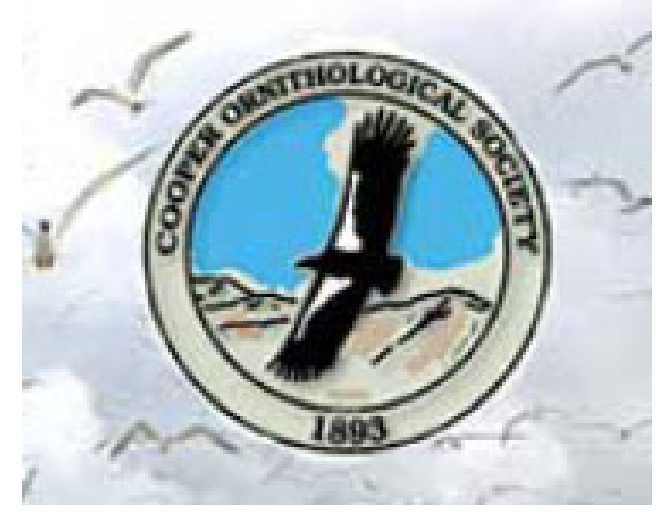

Body Weight and Feather Growth of Male Barrow's Goldeneye during Wing Molt Author(s): Debbie van de Wetering and Fred Cooke

Reviewed work(s):

Source: The Condor, Vol. 102, No. 1 (Feb., 2000), pp. 228-231

Published by: University of California Press on behalf of the Cooper Ornithological Society

Stable URL: http://www.jstor.org/stable/1370 430

Accessed: 23/04/2012 21:59

Your use of the JSTOR archive indicates your acceptance of the Terms \& Conditions of Use, available at http://www.jstor.org/page/info/about/policies/terms.jsp

JSTOR is a not-for-profit service that helps scholars, researchers, and students discover, use, and build upon a wide range of content in a trusted digital archive. We use information technology and tools to increase productivity and facilitate new forms of scholarship. For more information about JSTOR, please contact support@jstor.org. 


\title{
BODY WEIGHT AND FEATHER GROWTH OF MALE BARROW'S GOLDENEYE DURING WING MOLT ${ }^{1}$
}

\author{
DEBBIE VAN DE WETERING \\ Canadian Wildlife Service, 91782 Alaska Highway, Whitehorse, YT, Y1A 5B7, Canada, \\ e-mail: debbie.vandewetering@ec.gc.ca \\ FRED COOKE \\ Department of Biological Sciences, Simon Fraser University, 8888 University Drive, \\ Burnaby, BC, V5A 1S6, Canada
}

\begin{abstract}
We studied the timing, duration, and rate of wing molt of male Barrow's Goldeneye (Bucephala islandica). The mean daily change in primary feather length was $2.6 \%$, which is consistent with rates reported for other waterfowl species. The mean length of the flightless period was 31 days (range: 27-34 days), excluding the pre-shedding interval. Wing molt extended from early July to mid-September. Peak wing molt occurred between 20 July and 23 August. The mean body weight of adult males decreased significantly during wing molt. Heavier birds had greater remigial growth rates and experienced more substantial declines in body weight than lighter birds, suggesting that body reserves may be used to increase the rate of remigial growth.
\end{abstract}

Key words: Barrow's Goldeneye, Bucephala islandica, molt strategies, nutrient reserves, remigial growth rate, wing molt, Yukon.

The postbreeding period is an important part of the annual cycle of waterfowl, requiring increased energy and nutrients for feather synthesis and associated metabolic changes (Schieltz and Murphy 1997) and the accumulation of energy reserves to meet the costs of fall migration (Hohman et al. 1992). In addition, some birds become flightless during molt which potentially makes them vulnerable to predators and to changes in food availability. Energy and nutrient demands required for feather synthesis and other metabolic processes associated with molt may be met by (1) foods consumed in the diet, (2) endogenous reserves, (3) alteration in the timing, rate, and/or pattern of molt so that requirements match nutrient availability, or (4) a combination of the above adjustments (Murphy and King 1982). Changes in behavior, such as reduced time spent active, can partially compensate for the energy demands of molt (Murphy 1996) and can reduce exposure to predators.

Variability in the process of molt among species suggests that each species has evolved a molt strategy that is best suited to its own annual cycle and the environmental conditions in which it lives. In waterfowl,

\footnotetext{
${ }^{1} \mathrm{R}$
1999.

${ }^{1}$ Received 13 April 1999. Accepted 18 October
}

the wing molt occurs after peak energy demands of reproduction. Weight loss during wing molt is common among waterfowl (Hohman et al. 1992) and generally is interpreted as an adaptive strategy that permits birds to regain flight before primary feathers are fully regrown (Ankney 1979, Owen and Ogilvie 1979). However, few studies have investigated the molt of birds that live at high latitudes where seasonal time constraints favor rapid completion of molt (Mewaldt and King 1978). Birds that molt at high latitudes may have an accelerated molt and thus greater daily energetic and nutritional demands and increased reliance on endogenous reserves than birds molting farther south. Knowledge of the extent, rate, duration, and timing of molt in a species can help to evaluate the nutritional challenge of molt on a bird (Murphy 1996).

In this study, we investigate wing molt in male Barrow's Goldeneye (Bucephala islandica) north of the Arctic Circle. We describe the timing and duration of wing molt, and examine factors that may influence the rate of remigial growth.

\section{METHODS}

\section{STUDY AREA}

The Old Crow Flats is a $5,000 \mathrm{~km}^{2}$ lacustrine plain in the northern Yukon $\left(68^{\circ} \mathrm{N}, 140^{\circ} \mathrm{W}\right)$ that contains over $3,750 \mathrm{~km}^{2}$ of wetland suitable for waterfowl (Russell et al. 1978). The area is an important breeding, molting, and pre-migration staging area for approximately 500,000 waterfowl (Hawkings and Hughes 1995). It is one of only two sites where large numbers of male Barrow's Goldeneye are known to gather during molt. Lakes on the Old Crow Flats are characteristic of habitat used by molting ducks; the area is secluded from human disturbance, the lakes are uniformly shallow (van de Wetering 1997), and have an abundant and diverse invertebrate fauna (Canadian Wildlife Service, unpubl. data).

\section{CAPTURE METHOD AND MEASUREMENTS}

Drive-trapping of molting birds took place on five lakes in 1995. A single drive-trapping event occurred on each lake in July and was repeated in August. Birds were aged and sexed using wing plumage (Carney 1992) and/or cloacal characteristics. Adults (ASY) were defined as males older than two years of age, and subadults (SY) were males in their second year. Each 


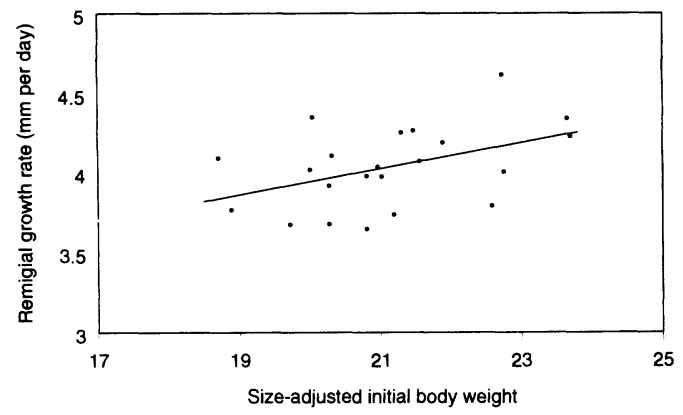

FIGURE 1. Relationship between remigial growth rate and size-adjusted initial body weight of adult male Barrow's Goldeneye during wing molt on the Old Crow Flats, $1995\left(r^{2}=0.19, P<0.05, n=22\right)$.

bird was banded and weighed to the nearest gram, and the length of the ninth-primary, total tarsus and culmen- 1 were measured to the nearest millimeter using the methods of Dzubin and Cooch (1992).

\section{STATISTICAL ANALYSES}

Males were considered to be in active wing molt if they had measurable new ninth-primary growth (visible pin feather). The mean ninth-primary length from captured birds retaining old primaries was used to estimate the length of a full, ninth-primary. We assumed that birds capable of flight could not be caught and estimated the percent re-growth necessary for flight by examining the percent ninth-primary re-growth of captured birds. We assumed ninth-primary growth remained constant and was representative of remigial growth. To estimate the length of the flightless period, we used the following equation: [(mean length of a ninth-primary $\times$ estimated $\%$ re-growth needed to regain flight)/mean remigial growth rate]. The timing of molt and the duration of the flightless period, excluding the pre-shedding interval, were determined by extrapolating start and end dates using the mean remigial growth rate of recaptured birds in active wing molt. Body weight was adjusted for structural size: [sizeadjusted body weight $=$ body weight/tarsus length].

Assuming constant rates of change in remigial growth and body weight, mean remigial growth rate $\left(\mathrm{mm}\right.$ day $\left.^{-1} \pm \mathrm{SE}\right)$ and mean change in body weight $(\mathrm{g}$ day $^{-1} \pm \mathrm{SE}$ ) were calculated from recaptured birds in active wing molt by dividing the difference between the first and second capture measurements by the capture interval. Analysis of variance was used to examine the relationships between rate of remigial growth and body weight change with capture location and male age. Linear regression was used to examine the influence of the timing of molt, primary length, and body condition on rates of remigial growth and body weight change. Values presented are means \pm SE. A $5 \%$ level of significance was used for all tests.

\section{RESULTS}

We captured 284 male Barrow's Goldeneye on 18-28 July 1995 and 215 males on 6-11 August 1995, including 61 recaptured birds. Of the 438 birds captured,

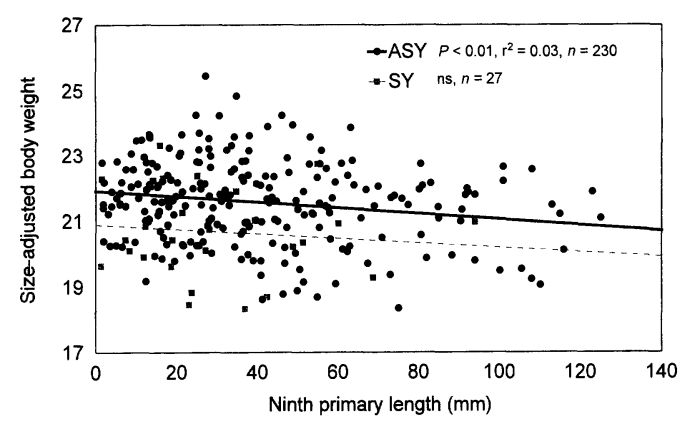

FIGURE 2. Relationship between size-adjusted body weight and ninth-primary length of male Barrow's Goldeneye (ASY and SY) during wing molt on the Old Crow Flats, 1995.

$90 \%(n=396)$ were classified as adult (ASY), $8 \%(n$ $=37)$ as subadult $(\mathrm{SY})$, and $1 \%(n=5)$ were of unknown age and excluded from the analysis.

\section{TIMING AND DURATION OF MOLT}

The mean ninth-primary length of retained old remiges $(n=9)$ was $155 \pm 2 \mathrm{~mm}$. Only four birds were captured with over $80 \%$ re-growth of the ninth-primary, whereas 30 birds were captured with over $70 \%$ regrowth. Thus, we assumed that most males could fly when their primaries reached $80 \%$ of their final length. The mean length of the flightless period, excluding the pre-shedding interval, was 31 days (range: 27-34 days). Wing molt extended from early July to midSeptember. The peak of molt (the period during which most birds were flightless) occurred between 20 July and 23 August.

\section{REMIGIAL GROWTH RATE}

The mean remigial growth rate of adult males in active wing molt $(n=22)$ was $4.04 \pm 0.05 \mathrm{~mm} \mathrm{day}^{-1}$. The mean daily percent change in feather length over the period of development was $2.6 \%$ (range: $2.4-3.0 \%$ ). The sample size of subadult males was too small for statistical analysis $(n=4)$, but the mean remigial growth rate $\left(4.14 \pm 0.15 \mathrm{~mm} \mathrm{day}^{-1}\right)$ was similar to that of adult males. Remigial growth rate was not significantly influenced by molt initiation date $\left(r^{2}=0.03\right.$, $P>0.40)$, stage of remigial growth $\left(r^{2}=0.01, P>\right.$ $0.70)$, or location of capture $\left(r^{2}=0.00, P>0.90\right)$. There was a significant positive relationship between remigial growth rate and size-adjusted initial body weight (Fig. 1).

\section{WEIGHT CHANGE}

The body weight of adult males in active wing molt decreased significantly as primary length increased (Fig. 2): a similar, although not significant, trend was observed in subadult males. Adults in active wing molt $(n=26)$ lost a mean of $1.84 \pm 0.46 \mathrm{~g} \mathrm{day}^{-1}$ between captures. Change in body weight during active wing molt was not significantly influenced by molt initiation date $\left(r^{2}=0.11, P>0.10\right)$ or location of capture $\left(r^{2}\right.$ $=0.01, P>0.90)$. There was a significant relationship between body weight change and size-adjusted initial body weight (Fig. 3). 


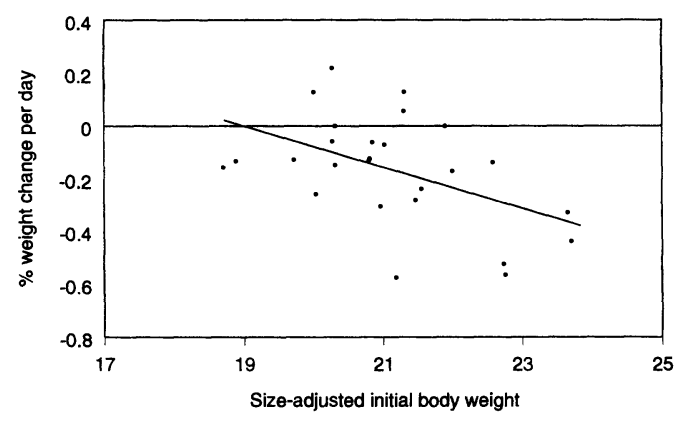

FIGURE 3. Relationship between weight change and size-adjusted initial body weight of adult male Barrow's Goldeneye during wing molt on the Old Crow Flats, $1995\left(r^{2}=0.28, P<0.006, n=26\right)$.

\section{DISCUSSION}

\section{TIMING AND DURATION OF MOLT}

The peak of wing molt of male Barrow's Goldeneye on the Old Crow Flats in 1995 was similar to dates reported for other waterfowl (Thompson 1992, Robertson et al. 1997). The flightless period for birds in our study was longer than the flightless period reported for species farther south (Mallards Anas platyrhynchos, Young and Boag 1981; Canvasback Aythga valisineria, Thompson 1992; Harlequin Ducks Histrionicus histrionicus, Robertson et al. 1997). Our estimate of $80 \%$ wing re-growth for flight may have contributed to the longer flightless period we observed, but it is possible that some sea ducks require longer remiges to regain flight due to high wing loading (large body weight to wing span ratio).

\section{REMIGIAL GROWTH RATE AND WEIGHT CHANGE}

The mean daily percent change in remigial length and weight change associated with molt observed in this study are consistent with patterns reported in other small-bodied waterfowl (see Hohman et al. 1992: Table 5-2 and Table 5-7). Unfortunately, there are few northern latitude molt studies with which to compare our data. The mean daily change in primary length observed in our study is less than that reported for male Green-winged Teal (Anas crecca) in northern Sweden $\left(4.6 \%, 63^{\circ} \mathrm{N}\right.$, Sjöberg 1988$)$ but similar to data for male Brant (Branta bernicla) in northern Canada $\left(2.73 \%, 77^{\circ} \mathrm{N}\right.$, Boyd and Maltby 1980$)$.

In waterfowl, variation in body weight has been at tributed to variation in physical condition rather than in structural size (Young and Boag 1982). Body weight change during molt has been linked to lipid storage and catabolism (Thompson and Drobney 1996) and to changes in endogenous protein levels (Hohman 1993). Assuming that size-adjusted body weight in our study reflected physical condition (defined here as the amount of endogenous nutrient reserves), then males in the best condition were able to use their endogenous reserves to achieve higher remigial growth rates than males in poorer condition. Costs associated with using endogenous reserves to increase the rate of remigial growth would likely be associated with decreased reserves available to ensure uninterrupted feather growth
(Douthwaite 1976) and/or body maintenance in the event of food limitation (Murphy 1996). Benefits of regaining flight quickly include decreased risk of predation and increased ability to find food and shelter. Weight loss associated with molt has been suggested to be an adaptive strategy that allows birds to reduce the amount of time spent flightless (Douthwaite 1976, Owen and Ogilvie 1979). Using endogenous reserves during wing molt also can be a behavioral strategy that allows birds to spend less time feeding and to occupy open-water habitats that reduce their risk of predation (Thompson 1992).

The advantages of weight loss may be reduced in diving ducks that use open-water habitats during the flightless period and dive to feed and escape from predators (Hohman 1993). However, early renewal of flight feathers may be beneficial for ducks molting in highly seasonal environments such as the Arctic. Early ice cover on lakes would likely be detrimental to flightless diving ducks as the areas accessible for feeding would be diminished, cold temperatures could reduce the availability of food, and birds could become entrapped in ice (King 1974; S. Boyd, pers. comm.). Our study suggests that molt was not a nutritionally challenging event for Barrow's Goldeneye on the Old Crow Flats. However, there did appear to be an advantage for male Barrow's Goldeneye to enter the flightless stage in good condition. Males in good condition may not only rely on endogenous reserves to meet the increased energy and nutritional costs of molt but also may be able to increase the rate of remigial growth and thus decrease the amount of time spent flightless.

We thank the Vuntut Gwitchin First Nation for their support and participation in this project. We thank P. Abel, B. Bennet, A. Breault, R. Francis, J. Hawkings, N. Hughes, M. Jules, D. Lord, M. Mossop, and G. Robertson for their assistance in the field. S. Boyd and T. Williams provided valuable suggestions regarding the design of the study. G. Robertson made helpful comments on an earlier draft of the manuscript. The Canadian Wildlife Service and the Polar Continental Shelf Project provided financial support.

\section{LITERATURE CITED}

ANKNEY, C. D. 1979. Does the wing molt cause nutritional stress in Lesser Snow Geese? Auk 96:6872.

Boyd, H., AND L. S. Maltby. 1980. Weights and primary growth of Brant Geese Branta bernicla moulting in the Queen Elizabeth Islands, N.W.T., Canada. Ornis Scand. 11:135-141.

Carney, S. M. 1992. Species, age and sex identification of ducks using wing plumage. U.S. Dept. Interior, U.S. Fish and Wildl. Serv., Washington, DC.

DouthwaIte, R. J. 1976. Weight changes and wing moult in the Red-billed Teal. Wildfowl 27:123127.

Dzubin, A., AND E. Cooch. 1992. Measurements of geese: general field methods. California Waterfowl Assoc., Sacramento, CA.

Hawkings, J. S., AND N. L. Hughes. 1995. Cooperative 
migratory bird and habitat studies Old Crow Flats, Yukon, Summer 1994-96. Internal Report, Canadian Wildl. Serv., Whitehorse, YT, Canada.

Hohman, W. L. 1993. Body composition dynamics of ruddy ducks during wing moult. Can. J. Zool. 71: 2224-2228.

Hohman, W. L., C. D. Ankney, and D. H. Gordon. 1992. Ecology and management of postbreeding waterfowl, p. 128-189. In B. D. J. Batt, A. D. Afton, M. G. Anderson, C. D. Ankney, D. H. Johnson, F. A. Kadlec, and F. L. Krapu [EDS.], Ecology and management of breeding waterfowl. Univ. Minnesota Press, Minneapolis, MN.

KING, J. R. 1974. Seasonal allocation of time and energy resources in birds, p. 4-87. In R. A. Paynter [ED.], Avian energetics. Nuttall Ornithol. Club Publ. No. 15.

$\rightarrow$ MewaldT, L. R., AND J. R. KING. 1978. Latitudinal variation of postnuptial molt in Pacific Coast White-crowned Sparrows. Auk 95:168-179.

MuRPHY, M. E. 1996. Energetics and nutrition of molt, p. 158-198. In C. Carey [ED.], Avian energetics and nutritional ecology. Plenum Press, New York.

MurPhy, M. E., AND J. R. KING. 1982. Amino acid composition of the plumage of the White-crowned Sparrow. Condor 84:435-438.

Owen, M., AND M. A. Ogilvie. 1979. Wing molt and weights of Barnacle Geese in Spitsbergen. Condor $81: 42-52$.

Robertson, G. J., F. Cooke, R. I. Goudie, AND W. S.
BoYD. 1997. The timing of arrival and moult chronology of Harlequin Ducks Histrionicus histrionicus. Wildfowl 48:147-155.

Russell, D., D. Mossop, AND C. Goodfellow. 1978. Remote sensing for waterfowl nesting and nesting habitat Old Crow Flats, Yukon Territory, Canada. PECORA IV-Conference, Sioux Falls, SD.

Schieltz, P. C., AND M. E. Murphy. 1997. The contribution of insulation changes to the energy cost of avian moult. Can. J. Zool. 75:396-400.

SJÖBERG, K. 1988. The flightless period of free-living male Teal Anas crecca in northern Sweden. Ibis 130:164-171.

Thompson, J. E. 1992. The nutritional ecology of molting male Canvasbacks (Aythya valisineria) in central Alberta. M.Sc. thesis, Univ. Missouri-Columbia, Columbia, MO.

Thompson, J. E., AND R. D. Drobney. 1996. Nutritional implications of molt in male Canvasbacks: variation in nutrient reserves and digestive tract morphology. Condor 98:512-526.

VAN DE WETERING, D. E. 1997. Moult characteristics and habitat selection of postbreeding male Barrow's Goldeneye (Bucephala islandica) in northern Yukon. M.Sc. thesis, Simon Fraser Univ., Burnaby, BC, Canada.

Young, D. A., AND D. A. BoAG. 1982. Changes in physical condition of male Mallards (Anas platyrhynchos) during moult. Can. J. Zool. 60:32203226.

\title{
COPULATION BEHAVIOR, MATE GUARDING, AND PATERNITY IN THE SEMIPALMATED PLOVER ${ }^{1}$
}

\author{
YURI ZHARIKOV ${ }^{2}$ \\ Watershed Ecosystems Graduate Program, Trent University, Peterborough, Ontario, Canada, K9J 7B8 \\ ERICA $\mathrm{NOL}^{3}$ \\ Biology Department, Trent University, Peterborough, Ontario, Canada, K9J 7B8, e-mail: enol@trentu.ca
}

\begin{abstract}
We present behavioral observations and multilocus DNA fingerprinting data on Semipalmated Plovers (Charadrius semipalmatus) breeding in the sub-Arctic. We predicted that, where a large time/energy investment by males during incubation and chickrearing is crucial for successful reproduction, both ex-

\footnotetext{
${ }^{1}$ Received 28 April 1999. Accepted 19 October 1999.

${ }^{2}$ Current address: Department of Zoology, University of Queensland, Brisbane, Queensland, QLD 4072 Australia, e-mail: yzharikov@zoology.uq.edu.au

${ }^{3}$ Corresponding author.
}

tra-pair copulation and fertilization rates would be low. Extra-pair copulations were infrequent (7\% of total copulations), as were within pair copulations $(0.44$ $\mathrm{hr}^{-1}$ ). Copulations occurred, on average 6.2 days prior to clutch initiation. Males spent $64 \%$ of their time in visual contact with their mates. Mate guarding during the laying period was significantly more pronounced in coastal neighborhoods of breeding birds than among solitary-nesting pairs. Extra-pair fertilizations occurred in $4 \%$ of families resulting in an extra-pair paternity rate of $4.7 \%$.

Key words: breeding densities, Charadrius semipalmatus, extra-pair paternity, multilocus DNA fingerprinting, open habitat, Semipalmated Plover. 